\title{
A Revised Democratic Critique of EU (Citizenship) Law: From Relative Homogeneity to Political Judgment
}

\author{
Päivi Johanna Neuvonen*
}

(Received 26 August 2019; revised 13 December 2019; accepted 24 December 2019)

\begin{abstract}
The mainstream democratic critique of EU law rejects the argument that standard EU citizenship rights have a democracy-enhancing effect within the EU Member States. This Article shows how the democratic critique can benefit from a critique of critique that is missing in the discussion on the democratic effects of EU law. From this perspective, the Article makes an original contribution to critical EU legal studies at three levels. First, the critique of essentialist binary oppositions revisits what is political in the interests protected under EU citizenship rights. Second, the Article demonstrates how an Arendtian theory of political judgment counteracts the mainstream democratic critique in assessing the effects of EU citizenship law on democratic politics. Finally, reopening the question of what the conditions for democracy are translates into a methodological argument that rejectionist critique must yield to a more developed critical methodology in EU legal studies.
\end{abstract}

Keywords: EU law; critical EU legal studies; democratic theory; political judgment; EU citizenship

\section{A. Introduction}

EU citizenship law has recently witnessed a more permissive approach to restrictions on migrant EU citizens' rights to residence and equal treatment. This development in the case law of the Court of Justice of the EU (CJEU) has provoked scholarly interest from multiple perspectives. ${ }^{1}$ While the curtailment of access to EU citizenship rights raises concerns about systemic exclusion and differentiation between EU citizens, the growing uneasiness about what some authors call the overconstitutionalization of EU law may simultaneously lend support to a stricter interpretation of

\footnotetext{
${ }^{*}$ Päivi Neuvonen is post-doctoral fellow at the Faculty of Law at the University of Helsinki and a CES visiting scholar 2019-20 at Harvard University (Spring 2020). The author thanks the anonymous reviewers of the German Law Journal and the organizers of the 'EU Citizenship@25: Main Achievements and Future Challenges' Conference at Radboud University (June 28-29, 2018) for their valuable comments and criticism on the earlier versions of this article.

${ }^{1}$ The main legal question in this context is how the Court interprets the accepted conditions and limitations on EU citizens' rights under Directive 2004/38, including Article 7(1)(b), on EU Citizens' Right to Residence After Three Months and Article 24(2) on the Restrictions on EU Citizens' Right to Equal Treatment. Directive 2004/38, on the Right of Citizens of the Union and Their Family Members to Move and Reside Freely Within the Territory of the Member States, 2004 O.J. (L 158) 77 (EC). For an overview, see, for example, Sandra Mantu \& Paul Minderhoud, EU Citizenship and Social Solidarity, 24 MAASTRICHT J. EUR. \& COMP. L. 703, 709-15 (2017). The case law also raises questions about the relationship between EU primary and secondary law, when migrant EU citizens can be regarded as sufficiently integrated into the host Member State, and how the Court's reasoning evolves over time. For examples, see Questioning EU Citizenship: Judges AND THE Limits OF Free Movement and Solidarity in the EU (Daniel Thym ed., 2017).
}

(C) The Author(s), 2020. Published by Cambridge University Press on behalf of the German Law Journal. This is an Open Access article, distributed under the terms of the Creative Commons Attribution-NonCommercial-NoDerivatives licence (http://creativecommons.org/ licenses/by-nc-nd/4.0/), which permits non-commercial re-use, distribution, and reproduction in any medium, provided the original work is unaltered and is properly cited. The written permission of Cambridge University Press must be obtained for commercial re-use or in order to create a derivative work. 
EU citizenship rights. One of the pressing questions in EU legal studies is therefore whether the more cautious interpretation of EU citizenship rights can be seen as a necessary act of deference to the legitimate interests of the Member States. Such a stance on the CJEU's side could arguably resonate both with respecting the EU legislature's mandate and with protecting national political self-determination against supranational interventions in the sensitive fields of social welfare and collective solidarity. These arguments gain additional normative weight when they are made in the name of democracy.

Democratic theory undoubtedly provides a relevant framework for analyzing the effects of EU law. ${ }^{2}$ It is therefore unfortunate that much of the ongoing discussion has focused on either supporting or rejecting the argument of over-constitutionalization, while, at the same time, the normative and methodological choices that direct the democratic critique of EU law have escaped closer scrutiny. In this Article, this lacuna in critical EU legal studies is addressed through a critique of critique, that is, by subjecting the democratic critique of EU law to a democratic critique. ${ }^{3}$ This exercise includes considering both how the democratic critique can justify the CJEU's post-Directive 2004/38 citizenship case law and where it may currently fall short of explaining the effects of EU citizenship rights on democratic politics. Overlooking the fact that democratic politics can have multiple, potentially conflicting, emphases conveys a problematic normative disposition in the democratic critique of EU law. Although such a critique builds on a valid concern about depoliticization as a possible side-effect of legal integration, it provides a one-sided picture of how EU citizenship rights affect democracy within the EU Member States.

In this Article, analyzing the effects of EU citizenship law on democracy is connected to what the conditions for democratic politics are. From this starting point, the Article will examine both the substantive and the methodological implications of broadening the theoretical horizon in critical EU law scholarship. As will be shown, the effects of EU citizenship rights on democratic politics look different depending on how democratic politics is conceptualized and whether the critical focus is placed on democratic internalities - such as citizens' capacity for political judgment - rather than on democratic externalities, such as the virtual representation of outsiders. That the mainstream democratic critique of EU law presents just one possible narrative of how EU citizenship rights affect democracy within the Member States is linked to the observation that the critical study of EU law does not currently attend to the intellectual commitments of critical democratic theory. This observation raises a methodological question about the roles and forms of critique in EU legal studies.

This Article will first summarize what the ascendant form of democratic critique argues about EU citizenship rights and on what basis it rejects the idea that the inclusion of non-national outsiders through EU citizenship rights could be democracy-enhancing. The Article will then problematize the way in which the mainstream democratic critique defines the nature of interests that are protected under EU citizenship law. This part of the Article draws on feminist political theory in challenging the normative public/private distinction and the binary opposition between insiders and outsiders-both of which currently shape the democratic critique of EU law. This analysis suggests that a revised democratic critique should move its focus from democratic externalities to democratic internalities. To that end, the Article will explain how EU citizenship rights can be viewed as indirectly democracy-enhancing insofar as they enhance the conditions for valid

\footnotetext{
${ }^{2}$ Consolidated Version of the Treaty on European Union, arts. 2, 10, 11, 12, July 7, 2016, 2016 O.J. (C 202) 1 [hereinafter TEU].

${ }^{3}$ This Article uses the term democratic critique of EU law to refer to a branch of EU legal studies that criticizes EU law for its presumed negative effects on democracy within the EU Member States. For more on this, see Section B. The broader terms critical EU legal studies and critical EU law scholarship are not confined to the democratic critique of EU law, although the democratic critique plays a central role in the critical study of EU law. It can also be argued that the notion of critical EU legal studies implies openness towards the findings of a critique of critique, whereas the concept of critical EU law scholarship may or may not entail such openness.
} 
political judgments within the EU Member States. The Article will also show how this critique of critique poses a three-fold challenge to critical methodology in EU legal studies.

\section{B. EU Citizenship Under Strain: The Mainstream Democratic Critique of EU Citizenship Rights in a Nutshell}

The democratic deficit of the European Union and the related question of how European integration could be democratized are familiar topics in EU law scholarship. The non-democratic mode of EU governance is contested not only because it compromises the legitimacy of European integration, but also because it estranges the political subject from the source of governing power. ${ }^{4}$ The democratic critique of EU law has reinvented this discourse by moving the focus of critical EU legal studies from the democratic credentials of the EU itself to what effects EU law may have on democratic politics within the Member States. In practice, the case law of the CJEU plays a central role in balancing national policy goals with the objectives of integration. The high degree of juridification raises the concern that legal integration controls questions that are political by nature. ${ }^{5}$ From the perspective of the citizen, this would mean that EU law may have an alienating effect both because it undermines the role of the individual as a political subject and because it primarily empowers a select group of non-national migrants. ${ }^{6}$ It is therefore not surprising that the constitutionalization of EU citizenship rights, in general, and of the rights of economically inactive EU citizens, in particular, are often put forward as examples of the potentially harmful effects of EU law on democracy.

The present controversies about EU citizenship rights originate in the Court's reference to a certain degree of financial solidarity between the Member States in the pre-Directive 2004/38 case law. ${ }^{7}$ The proportionality analysis quickly became the main tool for defining the limits of this solidarity. The decisive question in this context is "when does the enjoyment of EU citizenship rights constitute an unreasonable burden on the host Member State?" approached this question by giving a varying degree of importance both to the concerns of the national welfare systems and to the migrant EU citizen's degree of economic and social integration in the host Member State. This approach was recast by the more recent view that becoming an unreasonable burden cannot be established through an individual assessment - and that a more systemic approach must therefore prevail in deciding what limitations on EU citizenship rights are proportionate under Directive 2004/38. ${ }^{9}$ Although restrictions on EU citizenship rights are still

\footnotetext{
${ }^{4}$ See, e.g., J.H.H. Weiler, Ulrich R. Haltern \& Franz C. Mayer, European Democracy and Its Critique, 18 WeST Eur. POL. 4, 6-9 (1995); J.H.H. Weiler, The Constitution of Europe 264-65 (1999) [hereinafter Weiler 1999].

${ }^{5}$ See, e.g., Antoine Vauchez, The Transnational Politics of Judicialization. Van Gend en Loos and the Making of EU Polity, 16 EUR. L.J. 1, 6, 22 (2010).

${ }^{6}$ See, e.g., J.H.H. Weiler, Van Gend en Loos: The Individual as Subject and Object and the Dilemma of European Legitimacy, 12 InT'L J. Const. L. 92, 102 (2014); see also Gareth Davies, Democracy and Legitimacy in the Shadow of Purposive Competence, 21 Eur. L. J. 2, 20 (2015). For an early reference to alienation in this context, see also Weiler 1999, supra note 4 , at $342-43$.

${ }^{7}$ ECJ, Case C-184/99, Rudy Grzelczyk v. Centre public d'aide sociale d'Ottignies-Louvain-la-Neuve, ECLI:EU:C:2001:458, Judgment of Sep. 20, 2001, para. 44, http://curia.europa.eu/juris/showPdf.jsf?docid=46599\&pageIndex=0\&doclang=EN\& mode $=$ lst \&dir $=\& o c c=$ first $\&$ part $=1 \&$ cid $=3008727$.

${ }^{8}$ See Directive 2004/38, on the Right of Citizens of the Union and Their Family Members to Move and Reside Freely Within the Territory of the Member States, 2004 O.J. (L 158) art. 7(1)(b), art. 8(4) (EC).

${ }^{9}$ ECJ, Case C-333/13, Elisabeta Dano and Florin Dano v. Jobcenter Leipzig, ECLI:EU:C:2014:2358, Judgment of Nov. 11, 2014, para. 111 (Opinion of Advocate General), http://curia.europa.eu/juris/liste.jsf?num=C-333/13:
}

It is, in fact, scarcely conceivable that the assistance granted to a single applicant can amount to an intolerable burden on a Member State, however small the latter is. The legislature therefore necessarily had in mind the possible overall consequence of all individual applications when it allowed the Member States to require all applicants for residence to prove that they have sufficient resources and comprehensive sickness insurance cover in order to be able to reside for more than three months in the territory of a Member State other than that of which they are nationals. 
subject to the proportionality analysis, the assessment of EU citizens' degree of integration has made room for more generic exclusions on grounds of insufficient financial resources. ${ }^{10}$

The relationship between EU citizenship rights and welfare solidarity is a recurring theme in the critical study of EU law. The classic No-Demos thesis highlights that there is no political community that could provide democratic legitimacy for solidarity claims between the Member States, or between nationals of different Member States. ${ }^{11}$ This elevates the concern that making the European Union more relevant to its citizens might be costly for democracy. ${ }^{12}$ The democratic critique of EU law is also skeptical of the idea that individual rights and freedoms that are protected under EU law could be viewed as political rights in the sense that they would make the Member States more, rather than less, democratic. ${ }^{13}$ In particular, this critique stands against the argument that the inclusion of non-national outsiders could be viewed as democracy-enhancing. ${ }^{14}$ This discussion has primarily focused on the European Economic Constitution and the effect of economic free movement rights. ${ }^{15}$ However, because EU citizenship rights are based on a similar logic of restrictions and justifications, they have increased the number of situations in which the concern about the democratic effects of EU law materializes.

A prominent formulation of the democratic critique of EU law is included in Alexander Somek's analysis of what he calls an "argument from transnational effects." 16 Although Somek's work represents only one strand of the democratic critique, it is illustrative of the concerns that shape the mainstream democratic critique of EU law. This is so because Somek describes in detail what this type of critique assumes about democratic politics and how it relates to the rights that are granted to individuals under EU law. He also locates EU citizenship rights in that overall construction. ${ }^{17}$ As a result, Somek's work exposes issues that often remain hidden in more discrete, or less comprehensive, accounts of the democratic critique of EU law. For these reasons, the remaining part of this section uses Somek's version of the democratic critique of EU law to explicate how such a critique could justify the stricter interpretation of EU citizenship rights in the CJEU's post-Directive 2004/38 case law. This analysis focuses on how the democratic critique conceptualizes the nature of interests that are protected under EU citizenship rights. What is problematic from the perspective of this Article is that many of these conceptualizations have taken on a life of their own in critical EU legal studies.

A central tenet in critical EU law scholarship is that the promise of individual empowerment through transnational rights and freedoms is a poor replacement for political emancipation. ${ }^{18}$ The legal status of EU citizenship accordingly appears as an impoverished medium for advancing a

\footnotetext{
${ }^{10} I d$; ECJ, Case 67/14, Jobcenter Berlin Neukölln v. Nazifa Alimanovic and Others, ECLI:EU:C:2015:597, Sep. 15, 2015, http://curia.europa.eu/juris/liste.jsf?num=C-67/14.

${ }^{11}$ See, e.g., Weiler, Haltern \& Mayer, supra note 4, at 10-19.

${ }^{12}$ See, e.g., Alexander Somek, Solidarity Decomposed: Being and Time in European Citizenship, 32 Eur. L. REv. 787, 816 (2007) [hereinafter Somek 2007].

${ }^{13}$ See, e.g., Alexander Somek, The Argument from Transnational Effects I: Representing Outsiders Through Freedom of Movement, 16 EUR. L.J. 315, 319-20 (2010) [hereinafter Somek 2010 I].

${ }^{14}$ See, e.g., Joachim Blatter, Samuel D. Schmid \& Andrea C. Blättler, Democratic Deficits in Europe: The Overlooked Exclusiveness of Nation-States and the Positive Role of the European Union, 55 J. Common MKT. STUD. 449 (2017).

${ }^{15}$ See, e.g., Jussi Jaakkola, Enhancing Political Representation Through the European Economic Constitution? Regressive Politics of Democratic Inclusion, 15 EUR. CONST. L. REV. 194 (2019).

${ }^{16}$ See Somek 2010 I, supra note 13; see also Alexander Somek, The Argument from Transnational Effects II: Establishing Transnational Democracy, 16 EUR. L.J. 375 (2010) [hereinafter Somek 2010 II]. It is possible to separate two main lines of analysis in this context: (1) One concerns the effects of EU law on national democracy. (2) The other concerns the non-national model of democracy. However, what is important from the perspective of the present Article is that both of these critical inquiries build on a similar conception of democracy.

${ }^{17}$ Although Somek's main focus is on the Court's move from nationality discrimination to the market access in the context of economic free movement, he explicitly discusses EU citizenship rights e.g. in Somek 2007, supra note 12 and in ALEXANDER Somek, The Cosmopolitan Constitution (2014).

${ }^{18}$ See, e.g., Alexander Somek, The Individualisation of Liberty: Europe's Move From Emancipation to Empowerment, 4 Transnat'L Legal Theory 258 (2013).
} 
more political and/or social citizenship within the EU. ${ }^{19}$ However, the democratic critique of EU law goes beyond this point to argue that EU citizenship rights may simultaneously have a detrimental effect on the existing democratic systems and practices in the EU Member States. The main question in this context is whose interests ought to be represented within the Member States and what forms this representation should take. In replying to this question, Somek observes that protecting equal citizenship rights by means of judicial review can only advance representation "virtually", in the sense that "what it really seeks to avoid is that members of society are being treated as though they were inexistent." 20 It follows that EU law may undermine the actual representation that forms the cornerstone of national representative democracy. ${ }^{21}$

Thus, the mainstream democratic critique of EU law defines the argument for the democracyenhancing effects of EU law as a quest for virtually representing the interests of outsiders within the EU Member States. ${ }^{22}$ In this constellation, the prohibition of nationality discrimination, including EU citizens' right to equal treatment, is viewed as the main technique of virtual representation. ${ }^{23}$ There is arguably nothing "necessarily democratic" in interest representation through the legal principle of equality. ${ }^{24}$ On the contrary, the democratic critique of EU law suggests that the interests protected under EU citizenship law are problematic from the perspective of democratic politics because they secure private interests that are primarily granted to non-nationals. ${ }^{25}$ That is, the democratic critique of EU law does not just call into question the democratic credentials of transnational interest representation-but it is also critical of the nature of interests that are represented by EU citizenship rights. Both dimensions of this critique are rooted in a shared vision of what democratic politics should entail in the first place. The cogency of the democratic critique of EU law can therefore be assessed by having a closer look at its understanding of democracy.

The democratic critique, as discussed in this section, problematizes the inclusion of non-national EU citizens on grounds that it mitigates the "relative homogeneity" 26 that is viewed as a precondition both for collective welfare solidarity and for representative democratic politics in the EU Member States. This reflects the fact that the democratic critique of EU law tends to envisage a symbiotic relation between democracy, solidarity, and (national) cultural homogeneity-a relation that is far from unproblematic from the perspective of critical democratic theory. The preferred conception of democracy in the democratic critique of EU law proceeds from two main assumptions: First, it

\footnotetext{
${ }^{19}$ See, e.g., Floris de Witte, EU Law, Politics, and the Social Question, 14 German L.J. 581 (2013); see also Agustín José Menéndez, Which Citizenship? Whose Europe?-The Many Paradoxes of European Citizenship, 15 GERMAN L.J. 907 (2014); see also Agustín José Menéndez \& Espen D. H. Olsen, Challenging European Citizenship: Ideas and REAlities In CONTRAST (2019).

${ }^{20}$ Somek 2010 I, supra note 13, at 325 and 321-22 (drawing an analogy between belonging to a minority as "being a stranger in your own country" and the position of non-national EU citizens in the host Member State allows Somek to invoke John Hart Ely's theory of interest-representation in explaining the protection of rights under EU law in terms of virtual representation).

${ }^{21} I d$. at $324-26$.

${ }^{22}$ Somek 2010 II, supra note 16, at 389 (summarizing what he calls the argument from transnational effects: “... the argument is most convincing and uncontroversial where it embraces virtual representation. Accordingly, the interests of outsiders are understood to be represented inside any other national political process so long as such a process does not suffer from distortion by adverse national bias").

${ }^{23}$ Alexander Somek, The European Model of Transnational Democracy: A Tribute to Ernst-Wolfgang Böckenförde, 19 GERMAN L.J. 435, 453 (2018) [hereinafter Somek 2018]. Somek's more specific concern in relation to the prohibition of nationality discrimination is that prioritising equality over "actual representation" may result in combating what he calls "systemic discrimination," that is, "non-discriminatory difference between democracies." Somek 2010 I, supra note 13, at 327-30, 344. The prohibition of non-discriminatory obstacles to free movement, that is, the prohibition of systemic discrimination, arguably prioritises "market-building" over other types of “[c]onstitutional reasons." Somek 2010 I, supra note 13, at 333-34.

${ }^{24}$ Somek 2010 I, supra note 13 , at 325.

${ }^{25}$ See Somek 2018, supra note 23, at 452, 456.; see also Somek 2014, supra note 17 at 202-05, 260.

${ }^{26}$ Somek 2018, supra note 23 , at 446.
} 
holds that "there is an internal link between democracy and solidarity;" ${ }^{27}$ and second, it suggests that solidarity, understood as "mutual concern for one another," cannot be maintained "among total strangers." ${ }^{28}$ It follows from these two assumptions that relative homogeneity is viewed as a central condition for a "good democracy." 29 This logic is crystallised in the statement that " $t]$ he degree of homogeneity explains to which extent people agree to have their fate shared and to provide for their existential safety." 30

Somek suggests that homogeneity can be separated from any oppressive form of "uniformity" 31 and that homogeneity is not meant to extinguish otherness but "merely takes from it the taint of strangeness." 32 He also acknowledges that national culture is not "the only source of value" 33 and that our statements about culture are always "interpretative" and, thus, "contestable." ${ }^{4}$ Yet, viewing relative cultural homogeneity as a precondition for a good democracy supports the argument that undoing the link between democracy and the nation state would mean that "the boundedness of democracy loses its apparent naturalness" and that "those who are supposedly collectively self-determining lose the equivalent of their Superego." 35 The normative foundations of the democratic critique of EU law are more explicitly laid down in the proposition that "the (democratic) nation state undoubtedly represented the best possible institutional and cultural venue for translating a general disposition to support one's own folks into various efficacious means of intervention into society." 36

From this perspective, the mainstream democratic critique of EU law conceptualizes the argument from transnational effects, that is, the inclusion of outsiders by EU law, as a problematic attempt to create more homogeneity across the Member States. ${ }^{37}$ Because the willingness to share one's fate is presumably low(er) in a transnational polity, judicially protected rights become necessary tools for balancing conflicting interests. ${ }^{38}$ On this account, the non-national model of democracy would be liable for universalization through the inclusion of outsiders. ${ }^{39}$ The democratic critique of EU law, therefore, warns against the "proportionalisation of difference" 40 under EU law, as well as in the non-national models of democracy generally. ${ }^{41}$ Of note is that the democratic critique of EU law restricts this reasoning to the proportionalization of difference between

\footnotetext{
${ }^{27} I d$. at 439.

${ }^{28} I$ d. at $439-40$.

${ }^{29} \mathrm{Id}$. at 446.

${ }^{30} I d$.

${ }^{31} I d$.

${ }^{32}$ Somek 2010 II, supra note 16, at 382.

${ }^{33}$ Somek 2018, supra note 23, at 443.

${ }^{34} I d$. at 444 .

${ }^{35} I d$. at 450; see also e.g. Weiler, Heltern \& Mayer 1995, supra note 4 (showing a different perspective on the role and location of a "political boundary" in the democratic critique).

${ }^{36}$ Somek 2010 I, supra note 13, at 328. Somek has stated that "I am highly skeptical that idiosyncratic realisations of objective goodness within different polities ought to be subject to transnational debate." Somek 2010 II, supra note 16, at 390. However, Somek may have moved towards a more positive understanding of transnational democracy in his more recent work, provided that it follows the national, rather than non-national, model of democracy. See Somek 2018, supra note 23, at 447-48.

${ }^{37}$ Somek 2010 II, supra note 16, at 382 ("If creating homogeneity through the bridging of difference is what nations are all about the argument from transnational effects actually supports nation building. It overcomes the perceived failure of one nation state merely by enlarging its sphere.").

${ }^{38}$ Somek 2018, supra note 23 , at 454 .

${ }^{39} I d$. at $455-56$. Here the concern is that "universalisation presupposes an understanding of what is good for all" and that "[p]olitical processes are indispensable in order to establish common ground." Somek 2010 II, supra note 16, at 379 and 386. But Somek is not just worried about the lack of adequate political processes in the non-national model of democracy. For him, "the variety of objective goodness depends on boundaries, for they make it possible to experience otherness - the life of others whose purpose escapes one - as part of one's own social world." Somek 2010 II, supra note 16, at 388. This illustrates how the concern about depoliticization is mixed with cultural embeddedness in the democratic critique of EU law.

${ }^{40}$ Somek 2007, supra note 12 , at 816.

${ }^{41}$ Somek 2018, supra note 23, at 438, 455; see also Somek 2010 I, supra note 13 , at 338-39.
} 
the Member States, while its account of democratic politics can simultaneously be criticized for proportionalizing difference within the Member States. As will be seen in the next section, this is due to the binary oppositions that shape both the critique of interest representation and the critique of non-national democracy in the mainstream democratic critique of EU law.

\section{A Critique of Critique: What Is (A)political in EU Citizenship Rights?}

The democratic critique of EU law offers a justification for the stricter interpretation of EU citizenship rights in the CJEU's post-Directive 2004/38 case law. It does so by rejecting the idea that the inclusion of non-national EU citizens by means of individual rights and freedoms would have a democracy-enhancing effect within the Member States. Instead, the democratic critique of EU law depicts EU citizenship rights as potentially detrimental to national democratic politics. It has been seen in the previous section how this reasoning is based on the presumed concurrence of democracy, solidarity, and relative cultural homogeneity in the EU Member States. This section will consider what relevant critical insights the mainstream democratic critique of EU law might therefore be at risk of missing. This analysis first challenges the way in which the democratic critique conceptualizes the nature of interests that are protected under EU citizenship rights. It then moves the critical focus from democratic externalities to democratic internalities in assessing the effects of EU citizenship rights.

\section{Challenging the Binary Oppositions in the Democratic Critique of EU Law}

The democratic critique of EU law can be seen as an understandable counter-reaction to the neoliberal tendencies of the European Economic Constitution. At the same time, it is important to consider what kind of understanding of a political community and a political subject is emblematic of the critical study of EU law. This can be clarified by taking a closer look at how critical EU law scholarship conceptualizes the nature of interests that are protected under EU citizenship law. The mainstream democratic critique proceeds from two main assumptions: First, it depicts EU citizenship rights as apolitical because they focus on protecting private interests; second, conferring rights on non-nationals is seen as harmful to relative homogeneity that arguably forms a precondition for a good democracy. In assessing these claims vis-à-vis EU citizenship rights, it is necessary to revisit the conceptual framework that underpins the democratic critique of EU law. This metacritical ${ }^{42}$ exercise can benefit from considering how feminist political theory encounters the problem of essentialism and the cognate problem of binary categorization.

Essentialism is a fundamental conception in the internal discourse of feminist political theory. The basic notion of essentialism refers to the idea that "essence is prior to existence," meaning that things can be categorized through their essential characteristics. ${ }^{43}$ Classic liberal feminism is arguably vulnerable to essentialism in so far as it reduces human beings to natural categories. ${ }^{44}$ Essentialist feminism fails to recognize the effects of social formation on identity-formation and to take into account how gender and other forms of identity, such as class and race or ethnicity, intersect. ${ }^{45}$ In facing this issue, postmodern feminist theory seeks to deconstruct different binary categories in political and philosophical thinking. These oppositions can include, but are not limited to, the distinctions between "male and female; subject and object; public and private; form and substance; mind and body; active and passive; reason and emotion." ${ }^{46}$ The rationale behind this skepticism about binary oppositions is captured in the following statement:

\footnotetext{
${ }^{42}$ By metacritical, I refer to a mode of thinking that takes seriously the methodological commitment to a critique of critique. Using this term does not imply that any substantive formulation of a critique of critique could be unengaged.

${ }^{43}$ See, e.g., OXFORD LeXICO Dictionaries (2020), https://www.lexico.com/definition/essentialism.

${ }^{44}$ See, e.g., Ngaire Naffine \& Rosemary Owens, SeXing the Subject of LaW 8, 14 (1997).

${ }^{45} I d$. at 15.

${ }^{46}$ See Nicola Lacey, Feminist Legal Theory and the Rights of Women, in GENDER AND Human Rights 23, 27 (Karen Knop ed., 2004).
} 
The binary pairs of modern theories present particular and partial perspectives. They are discursive strategies for describing the world. They are already interpretations. ${ }^{47}$

From this perspective, binary oppositions can be examined as discursive categorizations that potentially conceal the unequal distribution of power within a political community. The important consequence is that a feminist challenge to binary oppositions is not limited to deconstructing gender differences. There exists a growing body of scholarship on how feminist jurisprudence can contribute to studying different areas of substantive EU law, including EU constitutional and citizenship law. ${ }^{48}$ However, the present Article is interested in how the feminist critique of essentialism can expose unhelpful conceptual structures in the democratic critique of EU law. ${ }^{49}$ This analysis problematizes both the normative public/private distinction and the binary opposition between insiders and outsiders in theorizing democracy. As such, it also opens the door for a revised conception of democratic politics in critical EU legal studies.

Viewing the promotion of private interests as a depolitcizing force lies at the heart of the mainstream democratic critique of EU law. The definition of private interests as apolitical is in line with the classic liberal understanding of the public and the private spheres as two distinct realms of human life, of which the former only is relevant to citizenship and democratic politics. ${ }^{50}$ The early feminist concern was that the areas of life that were defined as private fell outside the law and, thus, were subject to unregulated power relations. ${ }^{51}$ In contemporary feminist theory, the central argument is that inequalities created in the private sphere affect the person's ability to engage in democratic politics in the public sphere. ${ }^{52}$ At first, this critique seems to be fully in line with the concern that EU law constitutes nationals of the Member States as private persons, rather than as citizens and political actors. However, the feminist critique of the public/private distinction suggests that the issue of private interests is more complex than currently implied by the democratic critique of EU law.

Problematizing the categorical public/private distinction also problematizes the premise that protecting private interests under EU citizenship law is automatically apolitical. This point can be carved out by examining the different strands of the public/private distinction. One line of inquiry concerns the definition of public and private. Demarcating between public and private is a matter of interpretation and, as such, often political. ${ }^{53}$ It is also clear that the experiences of private and public spheres may diverge, for instance, depending on the person's "race, class and sexuality." 54 For this reason, defining something as categorically private or apolitical may

\footnotetext{
${ }^{47}$ Judith Greenberg, Introduction to Postmodern Legal Feminism, in MARY Joe FrUG, Postmodern Legal Feminisim (1992).

${ }^{48}$ See e.g. Susan Millns, Gender Equality, Citizenship and the EU's Constitutional Future, 13 EUR. L.J. 218 (2007); Dagmar Schiek, Broadening the Scope of and the Norms of European Equality Law: Towards a Multidimensional Conception of Equality Law, 12 MaAstricht J. Eur. \& Comp. L. 427 (2005); Jule Mulder, Promoting Substantive Gender Equality Through the Law on Pregnancy Discrimination, Maternity and Parental Leave, EUR. EQUALITY L. REV. 39 (2018); see also the work of Ruth Rubio Marín.

${ }^{49}$ This is not say that the feminist critique of essentialism would necessarily be free from essentialism. Moreover, for a critical perspective on the very idea of essentialism in the context of feminist theory, see, for example, Jane Roland Martin, Methodological Essentialism, False Difference, and Other Dangerous Traps, 19 SigNs 630, 638-39, 647 (1994).

${ }^{50}$ See, e.g., Margaret Davies, Taking the Inside Out: Sex and Gender in the Legal Subject, in SEXING THE SUBJECT OF LAW, supra note 44, at 38; Rosemary Hunter, Contesting the Dominant Paradigm: Feminist Critiques of Liberal Legalism, in THE Ashgate Research Companion to Feminist Legal Theory 19 (Margaret Davies and Vanessa Munro eds., 2013).

${ }^{51}$ See Lacey, supra note 46 , at 22.

${ }^{52}$ See Hunter, supra note 50, at 20; Nicola Lacey, Theory into Practice? Pornography and the Public/Private Dichotomy, 20 J. L. \& SOCIETY 93, 97 (1993).

${ }^{53}$ Hunter, Supra note 50, at 19; Margot Young, Gender and Terrain: Feminists Theorize Citizenship, in THE AsHgate Research Companion to Feminist Legal Theory 19 (Margaret Davies and Vanessa Munro eds., 2013).

${ }^{54}$ See Susan Boyd, Challenging the Public/Private Divide: An Overview, Challenging the Public/Private Divide: Feminism, LAW, AND Public Policy 12 (1997) (showing that there is arguably also less privacy available to those who are dependent on welfare benefits); see also Hunter, supra note 50, at 19.
} 
uphold the existing power relations in society. ${ }^{55}$ Another critical question in relation to the public/ private distinction is whether this distinction remains descriptive or whether it also becomes normative. ${ }^{56}$ In the latter case, the public/private distinction may contribute to the depoliticization of different structural disadvantages in society. ${ }^{57}$ On a more positive note, deconstructing this distinction can make room for a more inclusive notion of political. ${ }^{58}$

The feminist critique of the public/private distinction does not directly apply to the democratic critique of EU citizenship law because the term "private" holds different meanings in these two contexts. The mainstream democratic critique of EU law associates the notion of "private" with private economic interests. ${ }^{59}$ In contrast, feminist critique has traditionally equated it with the unregulated, above all, domestic/family life. ${ }^{60}$ Also noteworthy is the view that the ideological use of the public/private distinction can be seen as a characteristic of neoliberalism in law and governance. ${ }^{61}$ From this perspective, the feminist critique would support, rather than challenge, the concerns articulated by the democratic critique of EU law. Yet, the feminist critique of the public/private distinction suggests that defining EU citizenship rights as apolitical, on grounds that they protect private interests, is not the best way forward in analyzing the effects of EU citizenship rights on democracy in the Member States.

In sum, the critique of binary categorizations explains why the democratic critique of EU law should more explicitly distinguish between the argument that EU citizenship may foster harmful individualism, on the one hand, and the claim that EU citizenship rights are depoliticizing because their protect private interests, on the other hand. This is not to say that protecting individual rights could replace political emancipation. But a rigid normative distinction between public and private interests overlooks the fact that the protection of private interests has different implications for the political subject depending on one's starting point. ${ }^{62}$ Recourse to the public/private distinction in defining what is and is not political in EU citizenship rights is therefore vulnerable to the criticism that it over-simplifies the issue of depoliticization within the EU.

\section{Moving the Critical Focus from Democratic Externalities to Democratic Internalities}

Challenging the ideological distinction between public and private interests reopens the debate on what is political in the interests protected under EU citizenship rights, including the derived rights of EU citizens' family members. Defining these interests as apolitical may be more harmful from the perspective of disadvantaged groups than from the perspective of the more privileged nationals of the Member States. This means that the critique of the public/private distinction offers "another route to [the] consideration of issues of identity and difference" 63 within the Member States. While the democratic critique of EU law highlights that rights-based inclusion under EU citizenship law fails to meet the standards of democratic inclusion, it pays very little attention to how democratic inclusion may be inadequate, not only from the perspective of outsiders, but also from the perspective of many insiders. ${ }^{64}$ Thus, the democratic critique disregards

\footnotetext{
${ }^{55}$ See Hunter, supra note 50, at 19.

${ }^{56}$ Lacey, supra note 52, at 94 and 97-98, 103.

${ }^{57}$ Id. at 97.

${ }^{58} I d$. at 111.

${ }^{59}$ Note, however, that the democratic critique of EU citizenship law does not suggest that private interests protected under EU citizenship law would always be economic.

${ }^{60}$ See, e.g., Deborah L. Rhode, Feminist Critical Theories, 42 STANFORD L. REV. 617, 631 (1990).

${ }^{61}$ See Hunter, supra note 50, at 20; Boyd, supra note 54, at 19.

${ }^{62}$ See Lacey, supra note 46, at 39, 41-42 ("[S]cepticism about rights can be afforded only by the relatively privileged. For the more deeply oppressed, the language of rights still represents an aspiration and ideal; it can be deconstructed only once a prior political battle has been won.").

${ }^{63}$ Young, supra note 53, at 186.

${ }^{64}$ See, e.g., Somek 2018, supra note 23, at 456 notes in a footnote that "[n] ot just the external outsiders, the internal outsiders can be given a voice, too."
} 
the question of what transformative potential of EU citizenship rights could have in the realm of democratic internalities, as opposed to democratic externalities.

The democratic critique of EU law uses the concept of democratic externality to refer to national democracies dealing with non-national outsiders and other democracies. The assumption that democratic politics must always have boundaries entails that "[m]aintaining a bounded political community gives rise to adverse effects- 'externalities'-for outsiders." ${ }^{\prime 2}$ Placing the critical focus on democratic externalities in assessing the effects of EU citizenship rights on democracy is understandable in so far as the democratic critique of EU law aims to prove wrong the idea that "a major shortcoming of the democratic nation-state is the negligence of its external effects." ${ }^{66}$ From this perspective, the so-called argument from transnational effects appears as a claim that national democracies ought to become more "unbounded"-and this objective runs against the preferred conception of a good democracy in the mainstream democratic critique of EU law. ${ }^{67}$ But the analysis of democratic externalities is inadequate because it leaves unaddressed the question of negative democratic internalities - that is, of harm caused by factual, even if not formal, disenfranchisement within bounded national democracies.

The democratic critique of EU law does not entirely deny that free movement rights could be viewed as political. ${ }^{68}$ However, as has been seen in Section $B$, the democratic critique rejects the idea that these rights have democracy-enhancing effects within the Member States. This pessimism is connected to the fact that EU citizenship rights primarily protect interests of non-national outsiders who cannot fully participate in the democratic processes in the host Member State. Along with the distinction between public and private interests, the conceptual distinction between insiders and outsiders is central to the mainstream democratic critique of EU law. This distinction seems unproblematic if we adopt the view that all citizens are insiders in their capacity to be full members of a political community, while all non-citizens are outsiders, with no access to such a membership. But the critique of binary oppositions suggests that a categorical distinction between insiders and outsiders is also problematic. That is, recognizing that the private/public distinction may have differentiating effects within a political community accentuates the position of "insiders who are really outsiders" 69 within the EU Member States.

The distinction between insiders and outsiders appears particularly contentious when it is intertwined with the idea that there is a group of insiders whose desire to share their fate stems from their relative homogeneity. Such an assumption of homogeneous insiders undermines the fact that, in reality, both democratic politics and constitutional adjudication need to mediate different group interests. Therefore, binary opposition between insiders and outsiders promotes a misplaced account of virtual representation. The mainstream democratic critique of EU law confines the analysis of interest representation to democratic externalities and to the inclusion of outsiders - although the origins of this concept lie in scholarship that justifies the need for

\footnotetext{
${ }^{65} \mathrm{Id}$. at 451 . Somek contrasts national boundedness with a non-national perspective, under which "the prospect for individuals to be able to participate in processes of bounded political control explains why there have to be peoples" and under which the people "is supposed to facilitate the collective self-determination of citizens that are essentially private." Id. at $451-52$.

${ }^{66}$ Somek 2010 II, supra note 16, at 376, (quoting Joerges and Neyer, "Deliberative Supranationalism" Revisited, 2006/20 Working Paper, EUI LAW); see also Somek 2018, supra note 23, at 452, 455.

${ }^{67}$ Somek 2010 I, supra note 13, at 317-18, 320. Somek argues that either the inclusion of outsiders "would not be fair" or, "[i]f, however, the idea is that the insiders and the outsiders are part of a larger constituency the idefiniteness problem would arise." Somek 2018, supra note 23, at 458.

${ }^{68}$ For instance, Somek writes that “[w]ith regard to representation reinforcement through rights, Miguel Poiares Maduro's audacious claim is correct that the rights associated with freedom of movement are political rights. They are ... rights that force national legislatures to take the interests of those into account that are only inadequately represented." Somek, supra note 23 , at 456 .

${ }^{69}$ See, e.g., Zig Layton-Henry, Insiders and Outsiders in the European Union: The Search for a European Identity and Citizenship, in The Legal Framework and Social Consequences of Free Movement of Persons in the European UNION, 52-54 (1999).
} 
virtual representation from an internal democratic perspective. That a transnationalized form of virtual representation would regard "any democracy as good as any other" insofar as the interests of outsiders are adequately represented, ${ }^{70}$ is a peculiar conclusion in light of the fact that the very idea of virtual representation connects democratic legitimacy to how different groups are treated within a polity.

The diversity of life within the Member States, and not just between them, challenges the categorical distinction between private and public interests and the binary opposition between insiders and outsiders as the two key building-blocks in the democratic critique of EU law. These conceptual structures are unhelpful because they obscure the position of disadvantaged insiders within national democracies. ${ }^{71}$ It is important to consider whether, and if so how, EU citizenship rights affect democratic politics within the Member States. But, due to its focus on democratic externalities, the mainstream democratic critique of EU law cannot fully address the question of what effects EU citizenship law has on democratic internalities within the Member States. By not taking this latter dimension into account in its full complexity, the democratic critique of EU citizenship law presents an incomplete account of the democratic effects of EU citizenship law. This means that it may also fail to recognize where the transformative political potential of EU citizenship rights lies in the Member States.

\section{Retelling the Story: Democratic Politics, Political Judgment, and EU Citizenship Rights}

One starting point for European integration was that national majoritarian democracies can go astray at the level of democratic internalities. While the mainstream democratic critique of EU law condemns universalization at the expense of national particularity, it simultaneously reinforces conceptual oppositions that undermine the particularity of human life within national democracies. In particular, recourse to the binary oppositions between public and private interests and between insiders and outsiders prevents the democratic critique of EU law from fully grasping the issue of depoliticization that lies at the heart of its critical exercise. It is important to consider what alternatives can be offered to the idiom of "transnationally perfected democracy"72_ provided that the mainstream democratic critique is unhelpfully constrained by its conception of a good democracy. In this section, an Arendtian theory of political judgment provides an alternative framework for analyzing the effects of EU citizenship law on democratic politics. This analysis will extend to a methodological discussion on the role and forms of critique in EU legal studies.

\section{The Theory of Political Judgment as a Challenger for the Democratic Critique of EU Law}

Are the conditions for democratic politics secured in the EU Member States? The answer depends on what these conditions are. One way to approach this question is to move the critical focus from the patterns of democratic representation to what it takes for citizens to develop a capacity to exercise political judgment. That a theory of political judgment is needed to understand democratic politics lies at the heart of Hannah Arendt's political theory. Her argument-that plurality and adopting the standpoint of others through enlarged thinking are preconditions for valid political judgments - challenges the idea of relative homogeneity as the core of democratic politics in critical EU legal studies. However, as will be shown in this section, the culturally un-embedded

\footnotetext{
${ }^{70}$ See, e.g., Somek $2010 \mathrm{I}$, supra note 13, at 338 (suggesting that the principle of transnational virtual representation implies that "Other things being equal, any democracy is as good as any other.... As long as interests that are also had by foreigners are represented, no matter how strongly or weakly, foreigners are virtually represented in a democracy different from their own").

${ }^{71}$ Of course, it can also be pondered to what extent these disadvantages are heightened by European integration.

${ }^{72}$ Somek 2010 I, supra note 13 , at 340.
} 
performative reading of Arendt's political theory must compete with a communitarian interpretation of Arendt's thinking, in general, and of her argument about a judging community, in particular.

For Arendt, the two main features of a valid political judgment are non-subjectivity, on the one hand, and particularity, on the other hand. This means that genuine political thought must be other-regarding in a very particular sense. ${ }^{73}$ The concept of enlarged or representative thinking expresses the idea that a judging person must move beyond his or her subjective condition. Arendt locates the origins of representative thinking in Kant, but she suggests that Kant failed to grasp the "political and moral implications" of the critique of aesthetic judgment. ${ }^{74}$ Unlike Kant, Arendt embarks on exploring the faculty of critical judgment as a political activity. ${ }^{75}$ Obtaining impartiality that is arguably constitutive of critical judgment requires "that one can 'enlarge' one's own thought as to take into account the thoughts of others."76 This type of thinking would include "comparing our judgment with the possible rather than actual judgments of others, and by putting ourselves in the place of any other man." ${ }^{\prime 7}$ The cognitive faculty that makes this possible is imagination. ${ }^{78}$

Exercising political judgment through enlarged thinking means distancing oneself from "subjective private conditions." ${ }^{" 79}$ Arendt emphasizes that such distancing must not be confused with empathy. ${ }^{80}$ At the same time, she argues that non-subjectivity is "closely connected with the particulars." 81 Reconciling the seemingly conflicting conditions of non-subjectivity and particularity happens through publicity, which is understood as "contact with other people's thinking" 82 and "communicability." 83 This means that the validity of political judgment depends on the "presence of others." 84 Arendt uses the term "common sense" or "sensus communis" to clarify this point about political judgment as something that goes beyond a purely subjective condition. ${ }^{85}$ The central question in Arendt's theory of political judgment concerns what she means by sensus communis as a precondition for enlarged thinking and, thus, for the validity of critical/political judgment. This question is important because a communitarian interpretation of sensus communis would render Arendt's theory of political judgment largely redundant from the perspective of the present Article.

Arendt's idea of sensus communis indicates that "I judge as a member of this community and not as a member of a supersensible world." ${ }^{86}$ Some commentators suggest that her references to particularity mean that a judging community is always an "actual community," and that the "perspective of real others" is needed for the exercise of critical political judgment. ${ }^{87}$ However, it is not self-equivocal

\footnotetext{
${ }^{73}$ Hannah Arendt, Truth and Politics, in Between Past and Future: Eight Exercises in Politcal Thought 241 (1968) [hereinafter Arendt 1968].

${ }^{74} I d$. at 241. On Kant's critique of aesthetic judgment, see Immanuel Kant, Critique of the Power of Judgment, The Cambridge Edition of the Works of Immanuel Kant (Paul Guyer \& Erich Matthews trans., 2000).

${ }^{75}$ See Hannah Arendt, The Crisis in Culture: Its Social and Its Political Significance, in BETwEEn PAST AND FUTURE: EIGHT EXercises in Politcal Thought, supra note 73, at 219.

${ }^{76}$ Hannah Arendt, Lectures of Kant's Politcal 42 (Ronald Beiner ed., 1982) [hereinafter Arendt 1982].

${ }^{77} \mathrm{Id}$. at $42-43,71$. Arendt quotes Kant’s Critique of Judgment $\$ 40$. Note also Editor’s fn 155 , according to which Arendt has replaced Kant's word "universal" with "general" in this context.

${ }^{78} I d$. at 43

${ }^{79} \mathrm{Id}$.

${ }^{80} I d$. (stating that empathy is arguably constrained by subjective "prejudices" even if they no longer were the critics own prejudices).

${ }^{81} \mathrm{Id}$. at $43-44$.

${ }^{82} I d$. at 42 .

${ }^{83} \mathrm{Id}$. at 63 .

${ }^{84} I d$. at 64 .

${ }^{85} \mathrm{Id}$.

${ }^{86} I d$. at 67.

${ }^{87}$ Jennifer Nedelsky, Judgment Imagination, and Politics Themes from Kant and Arendt 109 (Ronald Beiner \& Jennifer Nedelsky eds., 2001) [hereinafter Beiner and Nedelsky 2001]. See also George Kaleb, The Judgment of Arendt in Beiner and Nedelsky 2001, at 135, for the argument that "people of the same society are similar enough for enlarged mentality to be possible."
} 
that involving the perspective of real others would necessitate a pre-political community or cultural homogeneity in the communitarian sense. ${ }^{88}$ It has been noted that Arendt did not cherish any vain hope that what she called "world alienation" could be cured by "cultural relatedness and integrity." 9 This pessimism may explain Arendt's emphasis on plurality and performativity in her theory of political action. ${ }^{90}$ A radically different interpretation of the judging community will therefore follow from attending to the performative aspects of Arendt's thinking.

The performative approach to politics holds that the political identity is always coupled with political action. ${ }^{91}$ As Zerilli puts it, the call is therefore "to rethink ... community as that which is at once presupposed and created anew in the practice of judgment." 92 This reading of sensus communis finds support from Arendt's own observation that " $[t]$ he solution to this riddle is Imagination ... the ability to make present what is absent." 93 Although Arendt rejects the idea of an abstract and universal judging community, her vision of sensus communis can be understood as something that is created by the exercise of the faculty of judgment itself. ${ }^{94}$ What is important from the perspective of the present Article is that this reconstruction of political judgment supports an anti-communitarian reading of Arendt's political theory. This is of particular interest to the democratic critique of EU law because it suggests that plurality is a precondition for, rather than an obstacle to, democratic politics.

Arendt also speaks of the "basic other-directedness of judgment." 95 She further clarifies that " $\mathrm{t}$ ] ruly political activities ... cannot be performed at all without the presence of others, without the public, without a space constituted by the many." ${ }^{\prime \prime 6}$ Arendt's theory of judgment has been praised for explaining why political judgment benefits from diversity. ${ }^{97}$ However, making a connection between plurality and the validity of political judgments raises a set of difficult questions about what a genuinely other-regarding perspective means in this context. ${ }^{98}$ Enlarged thinking seems to ignore the fact that inter-subjective relations often consist of asymmetrical power relations. ${ }^{99}$ How the other-regarding perspective can accommodate plurality, when the plurality includes inequality or disadvantage, is connected to a much broader question of how Arendt understands the political. Therefore, it is important to clarify how Arendt's emphasis on plurality relates to her critique of the social and, thus, to her distinction between the private and the public.

For Arendt, it was crucial to distinguish political from apolitical, or, non-political. ${ }^{100}$ She was concerned about the way in which the "emergence of the social realm" muddles the distinction between the public and the private spheres. ${ }^{101}$ Yet, a closer look at why Arendt defended this

\footnotetext{
${ }^{88}$ The editor of Arendt's Kant Lectures emphasises that, although Arendt's approach to sensus communis supports the idea of "collective action," it is not just "anti-individualistic" but also "anti-communitarian." Ronald Beiner, Reading Hannah Arendt's Kant Lectures, in ARENDT 1982, supra note 76, at 98-99.

${ }^{89}$ See Dana Villa, Hannah Arendt: Modernity, Alienation, and Critique, in Beiner and Nedelsky 2001, supra note 87, at $292,304$.

${ }^{90} I d$. at $299,304-05$ and 299.

${ }^{91} I d$. at 296.

${ }^{92}$ Linda Zerilli, Feminism ANd the Abyss of Freedom 156 (2005).

${ }^{93}$ ARENDT 1982, supra note 76 , at 65.

${ }^{94} I d$. at 71 ("[T]he sensus communis ... must include the idea of a sense common to all; i.e. the idea of a faculty of judgment which, in its reflection, takes account (a priori) of the mode of representation of all other men in thought.").

${ }^{95} I d$. at 68.

${ }^{96}$ Arendt, supra note 75 , at 217.

${ }^{97}$ Nedelsky, supra note 87 , at 109,114 .

${ }^{98} \mathrm{Id}$. at 116, 117 ("[T] he issue of diversity ... lays bare the full complexities the theory will ultimately have to address.").

${ }^{99}$ See Iris Marion Young, Asymmetrical Reciprocity: On Moral Respect, Wonder, and Enlarged Thought, in Beiner and Nedelsky 2001, supra note 87, at 212.

${ }^{100}$ Hannah Arendt, The Human Condition 30, 71 (1958) [hereinafter Arendt 1958]. Underlying this reasoning is the idea that the private sphere is "born of necessity," whereas the political sphere is "a sphere of freedom", and that the private/ public distinction therefore captures the distinction between "necessity" and "freedom."

${ }^{101} I d$. at 28 .
} 
distinction shows that her approach to democratic politics is not essentialist in the sense that has been criticized in Section C. Both Arendt's public/private distinction and her critique of the social emanate from the concern that society undermines the plurality that is a precondition for democratic politics and political judgment. The harmful "rise of society" accordingly refers to the elevation of homogeneity and cultural rootedness as the bases for democratic politics. This notion is captured by the following statement, which sets out that:

Because society becomes the substitute for the family, "blood and soil" is supposed to rule the relationships between its members; homogeneity of population and its rootedness in the soil of a given territory become the requisites for the nation-state everywhere. ${ }^{102}$

Thus, it is possible to reconcile Arendt's theory of political judgment with the critique of binary oppositions if the analytical focus is placed on how enlarged thinking, as the source of a judging community, affirms plurality - as opposed to affirming the standpoint of those who share the same private, cultural, condition. Moreover, although Arendt's normative public/private distinction appears problematic from a critical feminist perspective, her non-identitarian approach to democratic politics is in line with it. ${ }^{103}$ The important finding that emerges from this discussion on Arendt's political theory is that, in criticizing EU law for depoliticization, the mainstream democratic critique of EU law somewhat paradoxically draws on propositions that count as social, rather than political. This finding strengthens the argument that the democratic critique of EU law needs to revisit its understanding of democratic politics. That a more plural community might be a more political community also raises the question of whether the presence of nonnational EU citizens could enhance the conditions for democratic politics within the EU Member.

\section{Pluralizing the Democratic Critique of EU Citizenship Law: Substantive and Methodological Implications}

Arendt, too, would presumably be critical of the current state of democracy in the European Union, but her critique would differ from the mainstream democratic critique of EU law in important ways. In particular, Arendt's understanding of politics as something constructed and her emphasis on plurality as the condition for valid political judgments can be used to rethink the democratic critique in EU legal studies. This is so in spite of the fact that Arendt herself was a firm advocate of the public/private distinction. Arendt's thinking depicts "the simultaneous presence of innumerable perspectives and aspects" as the core of the public realm and the sphere of appearance. ${ }^{104}$ Conversely, the private condition is problematic insofar as it marks the absence of others. ${ }^{105}$ This means that the "political way of seeing" is not possible without the capacity to "see things from multiple perspectives." 106 It follows that moving the democratic critique from relative homogeneity and cultural rootedness to the conditions for political judgment has both substantive and methodological implications for the critical study of EU law.

Placing the critical focus on what enables nationals of the Member States to develop a capacity for political judgment suggests that EU citizenship rights can have an indirect democracyenhancing effect within the Member States. The central point in Arendt's theory of political judgment was that enlarged thinking must not be confused with empathy. ${ }^{107}$ She emphasized,

\footnotetext{
${ }^{102} I d$. at 256.

${ }^{103}$ See, e.g., Bonnie Honig, Towards an Agonistic Feminism: Hannah Arendt and the Politics of Identity, in FEMINISTS Theorize THe Politcal, 215-16, 226-27 (Judith Butler \& Joan Wallach Scott eds., 1992).

${ }^{104}$ Arendt 1958, supra note 100 , at 57.

${ }^{105} \mathrm{Id}$. at 58 ("private man does not appear, and therefore it is as though he did not exist").

${ }^{106}$ Zerilli, supra note 92 , at $139,146$.

${ }^{107}$ Arendt 1982, supra note 76 , at 43 .
} 
however, that "human distinctness," which is a characteristic of plurality, "is not the same as otherness." 108 The inclusion of EU citizens is different from the inclusion of just any non-nationals because EU citizens can hold a unique mediating position between the feelings of empathy, affinity, and solidarity, on the one hand, and a complete lack of sensus communis, on the other hand. From this perspective, the presence of EU citizens can increase plurality as a precondition for valid political judgments, understood in terms of enlarged thinking. The effect of EU citizenship rights is not confined to their direct beneficiaries, but their concurrent democracy-enhancing effect can also extend to non-moving EU citizens. ${ }^{109}$ Although this effect remains indirect and tentative, it can be viewed as strong-or vague - as the equally indirect and tentative alienating spill-over effect of EU citizenship rights.

It goes without saying that EU citizenship rights alone cannot democratize the project of European integration or uphold the conditions for democratic politics within the Member States. What is nevertheless important is that, from the perspective of democratic theory, the presence and the inclusion of non-national EU citizens does not necessarily have a detrimental effect on democracy within the Member States. On the contrary, interaction between national and non-national EU citizens may enhance citizens' capacity to exercise political judgment within national political communities. This finding demonstrates that the question of what effects EU citizenship rights have on democracy is more complex than what the mainstream democratic critique of EU law implies. Above all, the democratic effects of EU citizenship law depend on the selected conception of democracy and democratic politics.

It is easy to agree with the democratic critique of EU law when it defends the value of democratic politics. What seems more problematic is that the model of culturally rooted national democracy is often used as an unquestioned starting point for the democratic critique of EU citizenship rights. The meaning of democracy is not unequivocal or singular. Critical democratic theory highlights that the conception of democratic politics cannot be reduced to the institutionalized patterns of representation. ${ }^{110}$ For instance, Zerilli speaks of democracy as an "ongoing practice of creating new institutions and ways of living." 111 At the same time, different theories of radical democracy even challenge the statist idea of democracy. ${ }^{112}$ These admittedly passing reflections on the meaning of democratic politics illustrate that the mainstream democratic critique of EU law, with its emphasis on relative cultural homogeneity, presents just one possible counter-reaction to the allegedly depoliticizing effects of European integration.

It has been seen in this section that adopting an Arendtian approach to democratic politics can have substantive implications for assessing the effects of EU citizenship rights on democracy in the Member States. But acknowledging that the concept of democratic politics is open for different interpretations also unveils a set of important methodological choices in the critical study of EU law. ${ }^{113}$ The way in which politics is conceptualized shapes the way in which we pose questions about the membership in a political community. ${ }^{114}$ Similarly, how we conceptualize particularity and difference is constitutive of our preferred conception of politics. ${ }^{115}$ These references to

\footnotetext{
${ }^{108}$ Arendt 1958 , supra note 100 , at 176.

${ }^{109}$ From an Arendtian perspective, this effect would remain indirect insofar as EU citizens cannot fully contribute to the "space of appearance." On the "space of appearance", see ARENDT 1958, supra note 100, at 198-99.

${ }^{110}$ See, e.g., Chantal Mouffe, Feminism, Citizenship, and Radical Democratic Politics, in Feminists TheORIze THE POLITCAL, 370 (Judith Butler \& Joan Wallach Scott eds., 1992).

${ }^{111}$ Linda Zerilli, Castoriadis, Arendt, and the Problem of the New, 9 Constellations 540, 544 (2002).

${ }^{112}$ See, e.g., Alain Badiou, Metapolitcs 93 (Eng. trans., 2005) (arguing that democratic politics, understood as treating "the particularity of people's lives" according to the "universal prescription," necessitates first treating them in an egalitarian way because any type of "communitarian designation" is unthinkable from a genuinely democratic perspective).

${ }^{113}$ See, e.g., Elizabeth Frazer \& Nicola Lacey, Politics and the Public in Rawls' Political Liberalism, XLIII POL. STUD. 233,235 (1995).

${ }^{114}$ Diana Owen \& Linda Zerilli, Gender and Citizenship, 28 Soc’y 27, 27 (1991).

${ }^{115} \mathrm{Id}$. at 27.
} 
conceptual contingency support the argument that, as a methodological tool, critique can and should expose the contingent nature of different conceptual and normative frameworks. ${ }^{116}$ In EU legal studies, the impasse in extending the critical exercise to the underlying normative assumptions about democratic politics currently undermines the credibility of critique from a methodological perspective.

The missed potential of critique in exposing conceptual contingency is linked to a deeper ambivalence of critical methodology in EU legal studies. What tasks critique can attain depends on what meanings the term "critique" comprises in our thinking. ${ }^{117}$ This can be illustrated by contrasting rejectionist critique with immanent critique. ${ }^{118}$ The basic idea of immanent critique is that the standards of critique are internal to social practices that form the focus of critique. ${ }^{119}$ On the one hand, the immanent critique differs profoundly from transcendental critique. On the other hand, by using the recurrent social and political crises as its starting point, immanent critique can have more transformative potential than a purely internal social critique would have. ${ }^{120}$ In EU legal studies, the value of immanent critique lies in the way in which it allows new critical openings that take seriously the gradual transnationalization of social reality. However, if critique becomes purely immanent, it may have difficulties in embracing the perspective of the as-yet-unknown. This would be problematic in the context of European integration because a transnationalized social and political reality is still only just coming into being.

In the end, defining the viable roles of critique also depends on how the relationship between theory and practice is understood. ${ }^{121}$ In political theory, the notion of performativity challenges the idea of "metaphysical substance that precedes its expression." ${ }^{122}$ A revised relationship between theory and practice would then need to recognize different "first-order practices," along with the "second-order conceptual language," in articulating the aims of critique. ${ }^{123}$ From this perspective, critical democratic theory appears to be an inherently creative enterprise. ${ }^{124}$ This positioning of critique resonates with the element of a new beginning in the project of European integration. That European integration "emerged from ... an intellectual and philosophical wasteland" after "the moral bankruptcy of Europe" seems irrefutable. ${ }^{125}$ The EU accordingly comes across as a transformative, even if not transcendental, project. Bringing these trajectories together demands that the critical inquiry in EU legal studies expands both towards more contextual, presumably immanent, and more creative, presumably transformative, forms of critique. It is problematic if the role of critique is reduced to a singular vision-whether rejectionist or not.

\footnotetext{
${ }^{116}$ Lacey, supra note 46 , at 43.

${ }^{117}$ See, e.g., Costas Douzinas \& Adam Gearey, Critical Jurisprudence: The Political Philosophy of Justice 36-41 (2005); Panu Minkkinen, Thinking Without Desire: A First Philosophy of LaW 98, 119-20 (1999); see also Editorial Comments: The Critical Turn in EU Legal Studies, 52 Common MKT. L. REV. 881 (2015) (illustrating the context of EU legal studies).

${ }^{118}$ On the distinction between "rejectionist" and "immanent" critique, see, for example, Villa, supra note 89, at 289.

${ }^{119}$ See, e.g., Titus Stahl, What is Immanent Critique?, 1-2, 7 (2013), https://papers.ssrn.com/sol3/papers.cfm?abstract_id= 2357957.

${ }^{120}$ See, e.g., RAHEL JAEGGI, CRITIQUE OF FORMS OF LifE 174-75 (2018); for a reference to immanent critique in the context of European integration, see also Floris de Witte, Interdependence and Contestation in European Integration, 3 EUR. PAPERS 475, 497 (2018).

${ }^{121}$ See Linda Zerilli, Feminist Critique and Realist Spirit, 50 PHIL. \& RHETORIC 589, 600 (2017).

${ }^{122}$ Judith Butler, Performative Agency, 3 J. Cultural Econ. 147, 147 (2010).

${ }^{123}$ Zerilli 2017, supra note 121 , at 595, 599.

${ }^{124} \mathrm{Id}$. at $600-01$.

${ }^{125}$ Rosi Braidotti, Identity, Subjectivity and Difference: A Critical Genealogy, in THINKING DIFFERENTLY: A READER IN European Women's Studies 162 (Gabriele Griffin \& Rosi Braidotti eds., 2002).
} 


\section{E. Conclusion}

The first step in the democratic analysis of EU law is to define what the conditions for democratic politics are. How this primary question is answered directs what critical conclusions can be made about the democratic effects of EU citizenship rights in the EU Member States. In this Article, a critique of critique prompted a reappraisal of the mainstream democratic critique of EU law on substantive and methodological grounds. This analysis did not reject the concern about the potentially depoliticizing effects of EU citizenship rights, but it argued that the democratic critique of EU law currently builds on problematic assumptions of a good democracy. This critical exercise first reopened the question of what is political in the interests protected under EU citizenship rights. It then suggested that the mainstream democratic critique fails to do justice to the issue of depoliticization in its full complexity. Lastly, the Article drew on Hannah Arendt's theory of political judgment in rethinking the democratic effects of EU citizenship rights.

A revised democratic critique proposed that the inclusion of non-national EU citizens can have an indirect democracy-enhancing effect by enhancing the conditions for valid political judgments in the EU Member States. It also laid down a set of benchmarks for a more developed critical methodology in EU legal studies, which included the role of critique in exposing conceptual contingency, the choice between different forms of critique, and the relationship between practice and theory. These arguments together indicate that the discussion on the democratic effects of EU law is far from complete. It is more appropriate to talk about the democratic critiques of EU law in plural because the findings of critique depend on whether it proceeds from a retrospective, or a critical, commitment to democracy. The project of European integration has its roots in the fact that the essentialist visions of national democratic politics can have detrimental effects at the level of democratic internalities. As a result, a partial account of a democratic polity or of a democratic subject may do more harm than good to the critical study of EU law. Rather than offering a closure, this Article set out to broaden the parameters within which the democratic effects of EU law are discussed.

Cite this article: Neuvonen PJ (2020). A Revised Democratic Critique of EU (Citizenship) Law: From Relative Homogeneity to Political Judgment. German Law Journal 21, 867-883. https://doi.org/10.1017/glj.2020.48 